\title{
Negotiating research priorities
}

\author{
Sally Davies has been appointed head of NHS \\ research and development. She tells Geoff Watts \\ that she wants to build on the success of the \\ national cancer research network and do more \\ to involve patients
}

\begin{abstract}
Professor Sally Davies, glancing occasionally at the press office's minder across the table, is choosing her words carefully. Once or twice, and quite voluntarily, she retracts her first comment and substitutes something a shade more cautious-a sensible precaution when taking up a new and sometimes high profile job. But on one topic, the science of her specialty, she enthuses without restraint. Entirely apt in someone who's just become John Pattison's successor as director of NHS research and development.
\end{abstract}

Davies's specialty is blood. "The wonderful thing about haematology is that there's no other branch of medicine that gives you so much opportunity to look down a microscope and then talk to the patient. The fascination is in bringing molecular medicine into the clinic." Although this translation from laboratory to clinic is now happening in more and more specialties, haematology was still a pioneer in the process when Davies joined it in 1981.

Her original decision to choose haematology was fortuitous and taken partly for domestic reasons: "It gave me my evenings." But once she was in the specialty she found she loved it. "I'd started in paediatrics and decided I wanted to become more specialised. It's the way my brain functions. I like to be very focused. And when I'd got into haematology I became even more specialised. I did sickle cell disease."

As she still does. She remains a consultant at the Central Middlesex Hospital, London, running paediatric and adult clinics and doing a weekly ward round. "I understand what's going on in medicine-the problems and the issues. It gives me a reality."

This reality can be lost when you occupy a smart office with lots of staff in Whitehall's Richmond House, and your most frequent contacts are as likely to hold ministerial as medical appointments. Not that Davies's caution in talking about her new job results from her being a stranger to the world of medical management and policy making. Far from it. She became Pattison's deputy last year, and since 1996 she's been head of research and development for the North Thames area and for London as a whole.

It doesn't take a particularly astute observer to note that in holding a job at this level-at which women are still relatively fairly thin on the ground-Davies is exceptional. So is it personal ambition that's driven her to scale the upper heights of the ministry? She says not. Nor, despite having two children aged 9 and 12, does she feel she's had to make any significant sacrifices. "It's not ambition; it's values," she says. "I care about research and really want it to work. I believe that coming at it the way I do, which is consultative, may move it forward."

\section{Standing up to fellow \\ doctors is much easier}

than telling patients that they're dying

Consultative or not, she's had to shed the position of most doctors, who feel able to demand much for their particular interest in medicine and complain noisily when they don't get it. Davies has to face the reality engendered by almost daily interaction with politicians and then feed its consequences back to her profession. This must be a job that creates conflict.

Davies disputes this. "There are occasions when we can make recommendations to ministers and they, for good reason, feel that something should be done a different way. I think it would be silly of me to set it up so that it became a conflict. I'm here to serve ministers who've been elected by a democratic process."

And what about when she's telling her fellow professionals

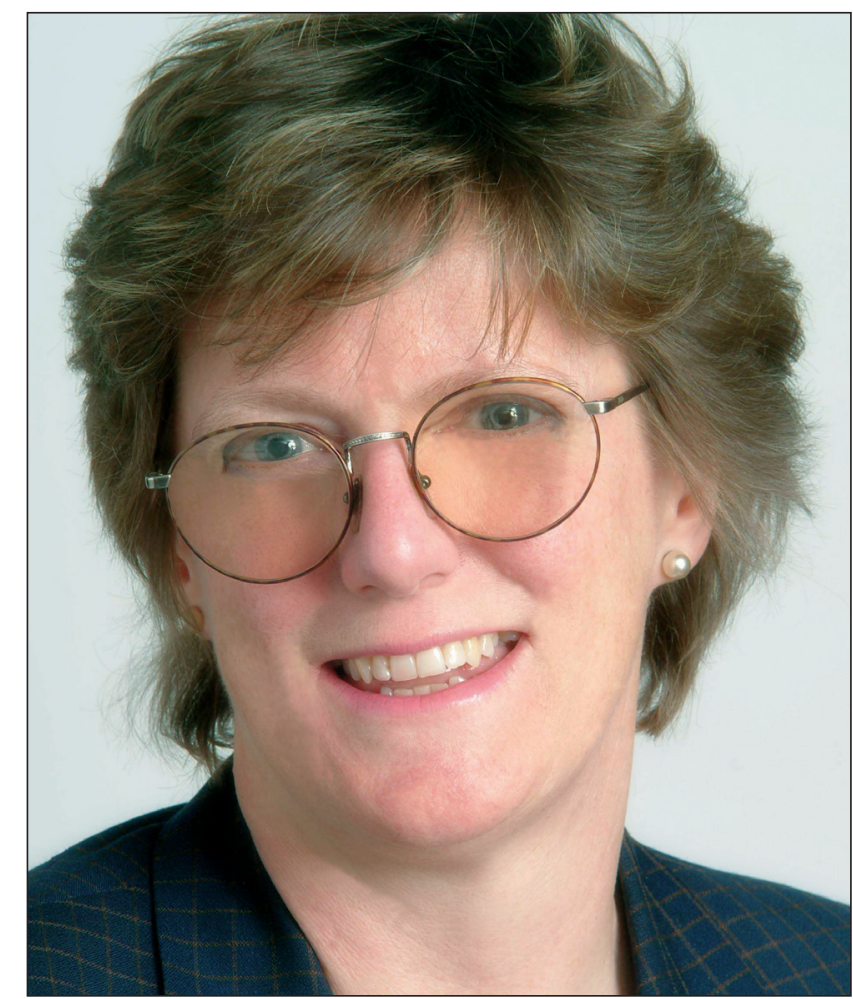

Sally Davies says that remaining a consultant "gives me a reality"

that they can't have everything they'd like? "My strength is that I'm very open and straightforward about it." She seems slightly taken aback by the suggestion that having to play such a role might prompt some people to view her as not always the easiest person to deal with. She adds (a touch unfairly or, depending on your point of view, irrelevantly) that standing up to fellow doctors is much easier than telling patients that they're dying.

And what of NHS research and development when her feet are firmly under the desk? She anticipates no major change, at least for the foreseeable future. Through schemes such as the national cancer research network she intends to build on what Pattison started. The network was created to provide the NHS with an infrastructure that would best support trials and other research by the cancer charities. Its success has prompted the creation of schemes intended to do something similar for other diseases, including Alzheimer's and stroke. "I think in 10 years when we look back we will thank him [Pattison] for this work he began in partnership with the other funders."

Davies is also keen on another idea: getting the subjects of medical research, the patients, more involved. "We are very proud in the NHS R\&D programme that we've led the way in involving consumers. I hate that word, I would like to say citizens-that we've involved citizens in the R\&D process." Does it work? "The occasions on which it throws up problems are when clinicians are not prepared to listen to patients. I'm really not politically correct about anything, but this I believe in tremendously."

\section{Involving citizens in} research throws up problems when clinicians are not prepared to listen to patients

To ask someone beginning a job that she's likely to hold for around five years what she'll do next is, to say the least, premature. So it's hardly surprising that Davies has no idea. When the moment comes, she says, she'll be content to continue in policy and management or to spend more time in the clinic and the research laboratory. Either will do-so long as, presumably, there's a good dose of science in the mixture. $\square$ Geoff Watts London 